\title{
PRODUCTION AND REGENERATION OF PROTOPLASTS FROM GREMMENIELLA ABIETINA AND ASCOCALYX ABIETIS*
}

\author{
Liliane Petrini and O. Petrini** \\ Tèra d'sott 5, CH-6949 Comano, Switzerland
}

(Received: August 31, 2000; accepted: October 5, 2000)

\begin{abstract}
This work was undertaken to develop a system of protoplast isolation and regeneration for G. abietina and A. abietis that could be of use for the genetic manipulation of both species. Nuclear staining was performed to assess the nuclear conditions of the protoplasts. Of the 19 enzyme complexes studied, only 10 were found to have some lytic effect on either Gremmeniella, A. abietis, or both. Only snail enzyme (from Szeged University), Novozym 234, lytic enzyme L1, or mixtures of snail enzyme and Novozym 234 produced satisfactory yields of protoplasts. Regeneration of protoplasts was observed on complete and on minimal medium, and occurred from protoplasts plated out directly onto the surface and from those embedded in the agarose. In most cases, embedding increased the frequency of regeneration. Protoplasts formed after incubation at $20{ }^{\circ} \mathrm{C}$ regenerated at a frequency of approximately $5 \%$, as opposed to $2 \%$ for those produced at $30{ }^{\circ} \mathrm{C}$. As roughly $40 \%$ of the protoplasts were anucleate, the percentage of regeneration can be estimated as about $12.5 \%$ at $20{ }^{\circ} \mathrm{C}$ and $5 \%$ at $30{ }^{\circ} \mathrm{C}$. Protoplasting appears to be a satisfactory method of obtaining material for genetic experiments with G. abietina and A. abietis when other methods are not directly applicable.
\end{abstract}

Keywords: Gremmeniella - Ascocalyx - genetics - protoplast formation - protoplast regeneration

\section{INTRODUCTION}

Gremmeniella abietina (Lagerberg) Morelet is a pathogen of conifers which causes economically important damages in the nurseries and pine plantations in the eastern U.S. and Canada [7]. Ascocalyx abietis Naumov is a saprobic species on coniferous hosts and is taxonomically closely related to G. abietina [5]. The taxonomic relationship of Gremmeniella and Ascocalyx is still debated. Petrini et al. [6] relegated the two species into separate genera on the basis of the morphological and biochemical characters. Both species readily produce the teleomorph and the anamorph on their host, but sporulation in culture is very irregular and has so far been induced only in one strain. Within G. abietina, two varieties and three races are known that cause cankers on their hosts, but the "European" race is a serious danger for older planta-

\footnotetext{
*Dedicated to Professor Lajos Ferenczy on the occasion of his 70th birthday.

**Corresponding author; e-mail: opetrini@pingnet.ch
} 
tions in the eastern U.S. and Canada $[2,4,7]$. The degree of gene exchange among these races, their mutual relationship and their relationship to A. abietis remain unclear.

This work was undertaken to develop a system of protoplast isolation and regeneration for G. abietina and A. abietis that could be of use for the genetic manipulation of both species. Nuclear staining was performed to assess the nuclear conditions of the protoplasts and to develop a system that could be used to elucidate the degree of ploidy of the races.

\section{MATERIAL AND METHODS}

\section{Strains used}

Three strains of G. abietina described in a previous study [6] were used. US-11 (European race) and C-1 (North American race) were isolated from Pinus spp. QFB 17097 was a representative of the var. balsamea [6]; the A. abietis strain (QFB 7492) was isolated from Abies balsamea.

Initially, all four strains were investigated in order to optimise protoplast formation, but for the final protoplasting experiments and nuclear staining only two strains, C-1 and QFB 7492, were used.

\section{Production of mycelium for protoplast formation}

Preliminary experiments showed that G. abietina grows rather poorly in liquid culture. Therefore, cellophane cultures were used throughout the whole study. Mycelium was produced on sterile cellophane sheets $70 \mathrm{~mm}$ in diameter placed on $90 \mathrm{~mm}$ malt extract agar Petri dishes (MA: 1\% malt extract, 2\% agar; Oxoid). Cellophane cultures were grown for 10 days at $20{ }^{\circ} \mathrm{C}$ from small mycelium fragments.

\section{Selection of osmotic stabiliser and enzymes}

Protoplast formation was tested by using commercially available enzyme complexes at a concentration of $0.5 \%(\mathrm{w} / \mathrm{v})$ for Novozym 234 and the other enzymes, and $0.5 \%$, $1 \%$ and $2 \%$ for snail enzyme (Table 1), dissolved in either sorbitol or $\mathrm{KCl}$ (both at concentrations of $0.6 \mathrm{M}, 0.8 \mathrm{M}$ or $1.0 \mathrm{M}$ ) as osmotic stabilisers. After sterilisation by filtration through sterile filters (Schleicher \& Schuell FP 030/2, membrane porosity $0.45 \mu \mathrm{m}$ ), the enzyme solutions were tested either alone or in paired combinations for enhanced activity. 
Table 1

Enzymes screened for protoplast production in G. abietina and A. abietis

\begin{tabular}{llll}
\hline \multicolumn{1}{c}{ Enzyme } & Manufacturer/Supplier & & Lytic activity on \\
\cline { 2 - 3 } & & G. abietina & A. abietis \\
Cellulase & Fluka & - & - \\
Cellulase & Szeged University & + & + \\
Cellulase & Merck & + & - \\
Cellulase & Calbiochem & - & - \\
Cellulase CP II & Sigma & - & - \\
Cellulase RS & Onozuka & + & + \\
Cellulysin & Calbiochem & + & - \\
Chitinase & Sigma & - & + \\
Chitinase & Sigma & + & - \\
Driselase & Fluka & + & + \\
Hemicellulase & Sigma & - & - \\
Lytic enzyme L1 & Szeged University & + & + \\
Macerase & Calbiochem & + & - \\
Novozym 234 & Calbiochem & + & - \\
Novozym 243 & Calbiochem & - & - \\
Pectinase & Fluka & - & + \\
Protease & Boehringer Mannheim (Roche) & - & - \\
Snail enzyme & Szeged University & + & - \\
Zymolyase 6000 & Seikagaky Kogyo Co. & - & \\
\hline
\end{tabular}

-: no activity; +: protoplast formation

\section{Protoplast formation}

The cellophane sheets with the colonies were placed upside down in $5 \mathrm{ml}$ of the sterilised enzyme solution in $90 \mathrm{~mm}$ plastic Petri dishes and incubated under gentle shaking $(60 \mathrm{rpm})$ at $20^{\circ} \mathrm{C}$ or $30^{\circ} \mathrm{C}$. While different concentrations of the osmotic stabilisers were used in the screening phase, only $0.7 \mathrm{M} \mathrm{KCl}$ was used in the subsequent experiments. Protoplasts released after digestion in the enzyme solution for 2 to $4 \mathrm{~h}$ were recovered by filtration through a sterile Duran glass filter (porosity 2 ) to remove undigested mycelium, and collected by centrifugation at $1200 \mathrm{~g}$ for $5 \mathrm{~min}$. After removal of the enzyme solutions, the protoplasts were washed twice in the osmotic stabiliser and re-suspended in $1 \mathrm{ml}$ of the stabiliser solution. Protoplast numbers were determined by using a Helber counting chamber.

\section{Protoplast regeneration}

Preliminary studies indicated that all enzymes that induced protoplast formation were nearly equally effective when dissolved in either sorbitol or $\mathrm{KCl}$, and that the strains did not grow well at high sorbitol or $\mathrm{KCl}$ concentrations (data not shown). All 
experiments were therefore performed with $0.6 \mathrm{M} \mathrm{KCl}$ as osmotic stabiliser (in the regeneration medium) or with $0.7 \mathrm{M} \mathrm{KCl}$ in the enzyme solutions. $\mathrm{MA}$ as complete medium and Neurospora minimal medium were used for protoplast regeneration. Although the strains investigated were known from previous experiments (Petrini \& Petrini, unpublished) to be autotrophic with respect to their vitamin requirements, 10 $\mathrm{ml} / \mathrm{l}$ modified Wickerham's solution [1] was added to the medium to stimulate growth.

For the regeneration experiments, the protoplasts were obtained by incubation of the mycelia in a mixture of $2 \%(\mathrm{w} / \mathrm{v})$ snail enzyme and $0.2 \%(\mathrm{w} / \mathrm{v})$ Novozym 234. The suspension of harvested protoplasts was diluted to contain approximately $10^{6}$ protoplast $\mathrm{ml}^{-1}$. Ten $\mu \mathrm{l}$ aliquots were spread directly onto the surface of osmotically stabilised complete or minimal medium or added to $3 \mathrm{ml}$ of $1 \%$ low gelling agarose type VII (SIGMA no. A-4018) dissolved in $0.7 \mathrm{M} \mathrm{KCl}$, cooled to $30^{\circ} \mathrm{C}, 35^{\circ} \mathrm{C}$ or 40 ${ }^{\circ} \mathrm{C}\left( \pm 1{ }^{\circ} \mathrm{C}\right)$, and the suspension was quickly spread onto $90 \mathrm{~mm}$ Petri dishes containing osmotically stabilised complete or minimal medium. The plates with regenerating protoplasts were incubated at $20^{\circ} \mathrm{C}$. The regeneration frequency was computed as the percentage of protoplasts that formed colonies after culturing for 15-30 days.

\section{Nuclear staining}

The protoplasts were fixed in a solution containing $0.7 \mathrm{M} \mathrm{KCl}$ and $25 \%$ ethanol. Nuclear DNA was stained by adding to the protoplast suspension the dye 4',6diamidino-2-phenyl-indole (DAPI, Sigma) dissolved in $0.7 \mathrm{M} \mathrm{KCl}$ to a final concentration of $1 \mu \mathrm{g} / \mathrm{ml}$.

\section{Protoplast formation}

\section{RESULTS}

Of the 19 enzyme complexes studied, only 10 were found to have some lytic effect on either the Gremmeniella strains, A. abietis, or both (Table 1). Only snail enzyme (from Szeged University), Novozym 234, lytic enzyme L1, or mixtures of snail enzyme and Novozym 234 produced satisfactory yields of protoplasts (Fig. 1). Strains US-11 and QFB 17097 also readily produced protoplasts when incubated in a mixture of snail enzyme and Novozym 234. The microscopic appearance of the protoplasts in the two strains was very similar, but the cells in A. abietis were slightly larger: they were spherical, vacuolated and up to $10 \mu \mathrm{m}$ in diameter.

Protoplast release started after incubation for $60 \mathrm{~min}$, and reached its peak after $180 \mathrm{~min}$. Longer incubation times did not noticeably increase protoplast production, regardless of the incubation temperature.

The amount of protoplast produced from C-1 or QFB 7492 was somewhat higher when the enzymatic process was carried out at $30^{\circ} \mathrm{C}$ : no change was observed in the percentage of nucleated protoplasts (Table 2). 


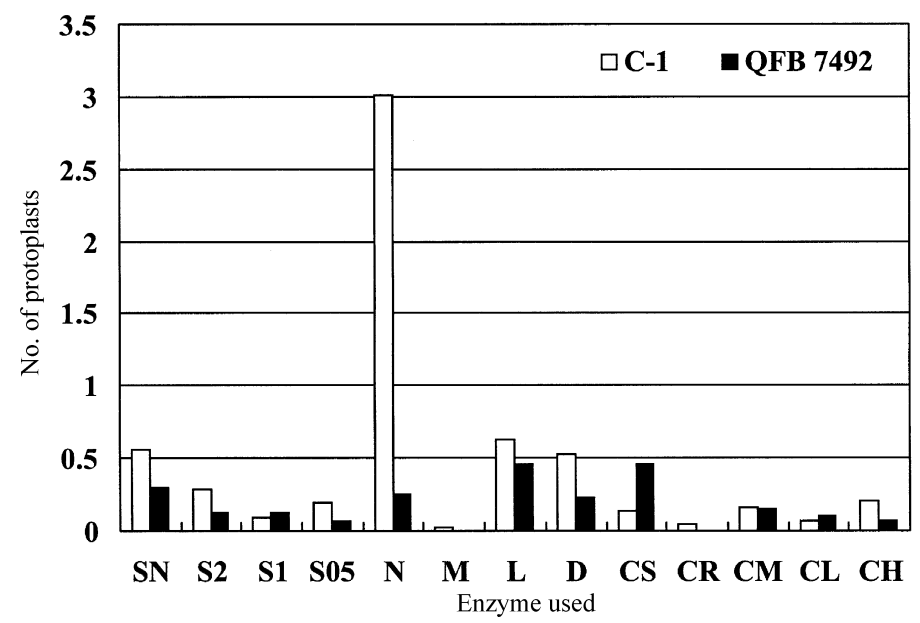

Fig. 1. Protoplast forming activity of selected enzyme complexes. Osmotic stabiliser: $0.7 \mathrm{M} \mathrm{KCl}$. Data are given as million protoplasts from $10 \mathrm{mg}$ fresh mycelial weight. Unless otherwise stated, all enzymes were used at a concentration of $0.5 \%$. CH: chitinase; CL: cellulysin; CM: cellulase Merck; CR: cellulase RS; CS: cellulase, Szeged University; D: driselase; L: lytic enzyme; M: macerase; N: Novozym 234; S05: snail enzyme; S1: snail enzyme, $1 \%$; S2: snail enzyme, $2 \%$; SN: snail enzyme, $2 \%+$ Novozym $234,0.2 \%$

Table 2

Release of protoplasts from C-1 and QFB 7492 at different temperatures (means of three repetitions) using $2 \%$ snail enzyme $+0.2 \%$ Novozym 234 as protoplasting enzymes

\begin{tabular}{cccccc}
\hline & \multicolumn{3}{c}{ Strain } \\
\cline { 2 - 3 } $\begin{array}{c}\text { Incubation } \\
\text { temperature }\end{array}$ & \multicolumn{3}{c}{$\mathrm{C}-1$} & & \multicolumn{2}{c}{ QFB 7492 } \\
\cline { 2 - 3 } \cline { 5 - 6 } & $\begin{array}{c}\text { Yield } \\
\left(10^{6} \text { prot./ml }\right)\end{array}$ & $\begin{array}{c}\text { Nucleated } \\
(\%)\end{array}$ & & $\begin{array}{c}\text { Yield } \\
\left(10^{6} \text { prot./ml }\right)\end{array}$ & $\begin{array}{c}\text { Nucleated } \\
(\%)\end{array}$ \\
\cline { 2 - 3 } $20^{\circ} \mathrm{C}$ & 46 & 30 & & 30 & 30 \\
$30^{\circ} \mathrm{C}$ & 104 & 30 & & 64 & 30 \\
\end{tabular}

\section{Protoplast regeneration}

The regeneration of protoplasts from G. abietina C-1 and A. abietis QFB 7492 appeared to be a slow process. In the whole set of experiments, the first protoplasts regenerating a cell wall and forming small colonies were observed after 5-7 days. In C-1, a hyphal tube developed directly from the protoplast and branching started 1-2 days later, whereas regenerating protoplasts of QFB 7492 formed first monilioid hyphae, from which branching hyphae emerged 3-4 days later. 
Table 3

Regeneration of protoplasts of G. abietina and A. abietis strains released after treatment with different enzymes, expressed as a percentage of the total protoplast counts

\begin{tabular}{cccc}
\hline Strain & $\begin{array}{c}\text { Novozym 234, } \\
0.5 \%\end{array}$ & $\begin{array}{c}\text { Snail enzyme, 2\%+ } \\
\text { Novozym 234, 0.2\% }\end{array}$ & $\begin{array}{c}\text { Lytic enzyme 1, } \\
0.5 \%\end{array}$ \\
\hline C-1 & 5 & 12 & + \\
QFB 7492 & 2 & 8 & + \\
\hline
\end{tabular}

$+:<1 \%$ regeneration.

Regeneration of protoplasts was observed on complete and on minimal medium, and occurred from protoplasts plated out directly onto the surface and from those embedded in the agarose. In most cases, embedding increased the frequency of regeneration. No differences in colony formation were observed between protoplasts embedded at $30^{\circ} \mathrm{C}, 35^{\circ} \mathrm{C}$ or $40^{\circ} \mathrm{C}$. Protoplasts formed after incubation at $20^{\circ} \mathrm{C}$ regenerated at a frequency of approximately $5 \%$, as opposed to $2 \%$ for those produced at $30{ }^{\circ} \mathrm{C}$. As about $40 \%$ of the protoplasts were anucleate, as determined by DAPI staining, the percentage of regeneration can be estimated as about $12.5 \%$ at 20 ${ }^{\circ} \mathrm{C}$ and $5 \%$ at $30{ }^{\circ} \mathrm{C}$.

The plating efficiency was also influenced by the enzyme (or enzyme mixture) used for protoplast formation: only $5 \%$ of the nucleated protoplasts regenerated after treatment with $0.5 \%$ Novozym 234 . Lytic enzyme L1 and the mixture of $2 \%$ snail enzyme and $0.2 \%$ Novozym produced comparable amounts of protoplasts. On the other hand, approximately $12 \%$ regeneration was achieved after treatment with the mixture, whereas no regeneration was observed for sphaeroplasts produced with L1 (Table 3).

No loss of viability by the protoplasts was observed when they were stored at $4{ }^{\circ} \mathrm{C}$ in the stabiliser for 2-3 days; older suspensions, however, yielded virtually no protoplasts.

\section{DISCUSSION}

The age of the starting cultures appeared to be crucial for protoplast formation. All strains grew comparatively slowly (a diameter of approximately $10 \mathrm{~mm}$ in 10 days at the optimum temperature of $20^{\circ} \mathrm{C}$ ), but cultures older than 10 days yielded no protoplasts when incubated with otherwise effective enzymes. Seven to ten-day-old colonies appeared to be most suitable for protoplast formation.

The release of protoplasts from C-1 and QFB 7492 when $2 \%$ snail enzyme $+0.2 \%$ Novozym 234 were used as protoplasting enzymes was somewhat higher at $30{ }^{\circ} \mathrm{C}$ than at $20^{\circ} \mathrm{C}$, with approximately the same yield of nucleated protoplast at the two temperatures (Table 2). Of all the enzymes tested, the highest lytic activity was 
shown by Novozym 234 at a concentration of $0.5 \%$. Nuclear staining, however, revealed that less than $20 \%$ of the protoplasts produced were nucleated, as opposed to $40-50 \%$ of the nucleated protoplasts produced with snail enzyme (alone or in combination with $0.2 \%$ Novozym 234 ) or lytic enzyme L1.

The regeneration frequencies for G. abietina and A. abietis protoplasts are comparable with those obtained by Yamada et al. [8], Yanagi et al. [9] and Hébraud \& Fèvre [3] for basidiomycetes. The colonies were slow-growing and exhibited the physiological properties of the colonies from which they were produced. The percentages of nucleated protoplasts of G. abietina and A. abietis were comparable to those described by Hébraud \& Fèvre [3] for the protoplasts of some mycorrhizal fungi.

G. abietina and A. abietis grow at comparatively low temperatures (maximum: 30 ${ }^{\circ} \mathrm{C}$ ). It is therefore no surprise that protoplast formation is optimal at their optimum growth temperature $\left(15-20^{\circ} \mathrm{C}\right)$.

Overall, protoplast formation in G. abietina and A. abietis proved to be successful, but the percentages of nucleate protoplasts were quite modest, thereby making the regeneration of new cultures difficult. Protoplasting appears to be a satisfactory method of obtaining material for genetic experiments with G. abietina and A. abietis when other methods are not directly applicable.

\section{ACKNOWLEDGEMENT}

We thank Prof. Lajos Ferenczy for his expert advice during his sabbatical at the Microbiological Institute, Swiss Federal Institute of Technology in Zurich, Switzerland, where the experiments were carried out. We are pleased and honoured to dedicate this paper to our friend and mentor Lajos on the occasion of his 70th birthday, in recognition of his merits in protoplast research.

\section{REFERENCES}

1. Booth, C. (1971) Fungal culture media. In: C. Booth (ed.) Methods in Microbiology, London, New York, Academic Press.

2. Dorwor, C. E. (1974) Comparison of soluble proteins of Ascocalyx abietis and Gremmeniella abieti$n a$ by serology and electrophoresis. Can. J. Bot. 52, 919-922.

3. Hébraud, M., Fèvre, M. (1988) Protoplast production and regeneration from mycorrhizal fungi and their use for isolation of mutants. Can. J. Microbiol. 34, 157-161.

4. Laflamme, G., Lachance, D. (1987) Large infection center of scleroderris canker (European race) in Québec province. Plant Disease 71, 1041-1043.

5. Müller, E., Dorworth, C. E. (1983) On the discomycetous genera Ascocalyx Naumow and Gremmeniella Morelet. Sydowia 36, 193-203.

6. Petrini, O., Petrini, L. E., Laflamme, G., Ouellette, G. B. (1989) Taxonomic position of Gremmeniella abientina and related species: a reappraisal. Can. J. Bot. 67, 2805-2814.

7. Skilling, D. D. (1981) Scleroderris canker development of strains and potential damage in North America. Can. J. Plant Pathol. 3, 263-265.

8. Yamada, O., Magae, Y., Kashiwagi, Y., Kakimoto, Y. (1983) Preparation and regeneration of mycelial protoplasts of Collybia velutipes and Pleurotus ostreatus. Eur. J. Appl. Microbiol. Biotechnol. 17, 298-300.

9. Yanagi, S. O., Monma, M., Kawasumi, T., Hino, A., Kito, M., Takebe, I. (1985) Conditions for isolation of and colony formation by mycelial protoplasts of Coprinus macrorrhyzus. Agaric. Biol. Chem. $49,171-179$ 
